\title{
International Modes of Policy Influence: Does the EU Influence Good-Governance Policies in African, Caribbean and Pacific States?
}

\author{
Joachim, T. Mugyenzi \\ Formerly-Department of Politics and International \\ Relations University of Kent, Canterbury, Kent CT2 7NZ, U.K. \\ Tel: 44-799-971-7682 \\ E-mail: joachimmugyenzi@ymail.com
}

Received: November 17, 2011

Accepted: December 20, $2011 \quad$ Published: March 1, 2012

doi:10.5539/jpl.v5n1p69

URL: http://dx.doi.org/10.5539/jpl.v5n1p69

\begin{abstract}
The European Union is able to transfer its values and influence good governance policies in ACP states, through leverage and transnational networks. This paper tries to establish the leverage-transnational networks nexus in influencing policy and to account for the variance of European Union influence. In a comparative design, it tries to extricate these influences empirically by using a multi-variate regression analysis for the years 1975-2009, to establish whether European Union influences good governance policies in the African Great lakes states of Kenya, Uganda and Tanzania. Though the analysis controls for other influences, still evidence of European Union influence in the three countries is significant. It further indicates that the degree of influence is predicated on the complementary role of the modes of influence, which accounts for the variance.
\end{abstract}

Keywords: European Union, Good governance, Linkage, Leverage, African great lakes countries

\section{Introduction}

Within, the broader context of international cooperation; the European Union has come under intense scrutiny for its interests. These interests are aimed at achieving 'milieu goals' for the economic and political stability of third countries. The European Union (EU) Council meeting on $28^{\text {th }}$ October 2010 in Brussels stressed that its foreign policy was the most important of all policies, because it has facilitated its Central and Eastern European countries (CEECs) expansion and streamlined its development cooperation agenda.

The EU, Common Foreign and Security Policy (CFSP), aims at transferring, in ranging levels, rules of conduct that presuppose political, social and economic, which in the long-term determine the nature and shape of EU interests in third countries. These rules entail good governance, which is sound economic policies, competent public administration, and an open accountable government together with polices aimed at combating corruption that characterise the interstate system of the EU.

According to the EU-African, Caribbean and Pacific (ACP) Cotonou partnership agreement of 2000-2020 (Article 8.4), good governance policy concept is a 'fundamental element' of the tie-in with ACP countries; this broadly provides grounds for its transferral, as a means to influence domestic policies of ACP states. More specifically, the EU creates rules and policies as well as their implementation in the domestic political system of ACP states. Predominantly, the EU through CFSP is able to influence good-governance policies and their outcome, by relying on the CFSP economic and financial instruments, such as European Union Development Fund (EDF), in which EU standards of behaviour are embedded.

In the recent years, EU promotion of good-governance as a policy has received some attention (Zanger, 2000; Youngs, 2001; Neumayer, 2003b; Schimmelfenning and Sedelmeir, 2004). These Studies concur on a number of substantive findings regarding EU use of leverage to promote good-governance. Nonetheless, they manifest design methodological issues, by providing a partial analysis on the role played by the EU in policy influence. They do not recognise the role of transnational networks in good governance promotion; neither make an attempt to disentangle the modes of influence and their complementary role. 
In this paper, I analyse the effects of modes available to the EU, in influencing African great lakes region states to adopt good-governance policies, account for the variance in influence and explore the complementary role of the modes. This is done by using cases of three countries, Uganda, Kenya and Tanzania from 1975-2009, augmented by interpreting policy as the linkage between intentions, actions, statements, values and results the EU actor uses to advance his objectives and shape policies in these countries. Finally, to observe the effects of EU influence on the three states and to rigorously test the degree of influence in these countries, I have expanded the data set to a comparative regression analysis.

What I find is, basically, that EU influence of good governance policies through leverage, is significant but the influence is more effective where transnational networks are well established. In addition, the degree of influence of good governance policies in Uganda, Kenya and Tanzania is better explained by an inclusive analysis of both linkage and leverage mechanisms. The study further indicates that the variance in good governance policies in the three countries is inversely related to the degree of linkage.

The Article is organized as follows: The next section discusses modes the EU can use to transfer policies and influence the domestic context in ACP states as well as their supporting roles. The third section, describes the method and data employed, while the fourth section, presents the empirical analysis. The final section discusses the policy implications and concludes.

\section{Modes of Policy Transfer and Influence Available to the EU}

This article identifies two broad modes through, which the EU is able to influence policies in third countries.

\subsection{Leverage}

This entails power relations between the EU and third countries. It is the exposure of these countries to EU pressure in a bid to force them to adopt good-governance policies. It involves the direct use of power, with the promise of reward (or threat of punishment) for adopting and implementing an agreed upon policy. EU leverage to the African Great Lakes states is typified by conditionality bargains, which takes place under the partnership agreements and trade leverage exerted by corporations from the EU, which operate in these states.

EU Aid Leverage on these countries is rooted in the practise of 'Policy Dialogue' enshrined in the EU-ACP successive Lome-Cotonou partnership agreements. According to the Courier 1982 (76), policy dialogue was to enable the EU to ensure that the chosen policies of its aid recipients were consistent with EU agreed upon policies for financial support. EU conditionality is mainly positive, in that the EU offers and with holds carrots but does not carry a big stick (Smith, 2001; Youngs, 2001). The practice is a deliberative process enshrined in transparency and monitoring, such that the countries, which fail to implement the desired policies are denied economic assistance or conditions for continued support are revisited through a discursive process.

The common form of leverage, which takes place between the EU and the three countries, is the conditionality bargains on EDF aid. Leverage mechanisms are easier to identify and they are mainly on the EU-ACP aid and trade policies. Here leverage is between the EU and the three individual states but can be assumed by different players like multinational companies that originate from the EU and operate in these countries. These multinational companies are able to demand changes in government polices, which resemble those practised in their home states.

According to the 1969, Arusha Agreement between the EEC and the East African Community states, increasing trade between the two parties and the international community was paramount (Article 1, Arusha, Agreement). As a consequence, trade has become one of the main mechanisms the EU uses to influence the three countries. The Everything But Arms Initiative (EBA) under the Cotonou Agreement (Holland, 2002) has strengthened this practise. The heavy reliance of those countries on the EU for their exports makes them vulnerable to EU demands, providing an opportunity to influence them with policies that mirror EU preferred style of governance. The desire by these countries to maintain the EU lucrative market for their commodities, indirectly forces them to implement EU desired policies in their domestic environments.

The popular form of trade leverage between the two parties has taken place under the Lome and Cotonou frameworks. Under the frameworks these countries have been influenced to implement specific standards for their exports, which enter the EU market. Such standards reflect practices of EU retailers Good Agricultural Practises (UREPGAG). A need to implement these policies in third countries has led to the participation of civil society in trade issues as a consultation mechanism for formulating liberal trade policies.

\subsubsection{Linkage}

This entails economic, political, and ideological links, which exist between the international system and the domestic environment. There is a propensity of some groups in these countries to identify themselves with the 
interests and outlook of the EU actors and to support patterns and polices that reflect them. These trans-national exchanges are diverse (Stallings, 1995; Levistsky and Way, 2006; Schimmelfenning and Scholtz, 2008; Burnell and Schlumberger, 2010) and their effects vary according to the level of interaction. The effect of these interactions on good-governance in these countries depends on the intensity of each linkage and how rooted it is in society.

The existence of these trans-national linkages, affects the population of these countries in different ways. Social linkage and the spread of ideas from the EU and other Western states is responsible for adoption of good governance policy concept by these countries, as demanded in these agreements with EU and the International Financial Institutions (IFIs). This has resulted in the implementation of good governance policy packages that resemble those advocated by the EU as an ideological guide. To a greater extent, the existence of trans-national influences creates a structure through, which these countries must operate, without being directly compelled. For example, trading norms such as the transfer of funds to and within these countries must be carried out, according to agreed transparent standards that epitomize EU policies, which must be implemented by these countries.

Furthermore, transnational networks transmit ideas to the local domestic societies of these countries. This ideational influence downplays the role of power and interests because it is close to society than the power wielded by the EU on the state. In the process interests and power (leverage) directed at governments by the EU is complemented, informed or based upon knowledge and ideas from these networks (Haas, 1990). It is on this basis, that linkage plays a great role in influencing society, as ideas transmitted by transnational networks become part of it. Transnational links tend to be more effective in influencing these states to adopt EU demanded good governance policies, because the demands tend to come from within their domestic societies. They embed social capital by creating the networks of trust, mutual assistance and reciprocity which help to connect society. Through the transmission of ideas they are able to reinforce relations and connections between people, which are important building blocks in the social cohesion of civil society as a major player in good governance influence (Kalu, 2004:79; Stoker, 2006:55).

Besides, some of the transnational links succour economic development, broadly entailing better education, less poverty, a large middle class as well as a better civil service; the so called wealth theory of democracy, which Lipset identified as requisites to democracy (Lipset, 1960:31; Pourgerami, 1991). Economic development sustains and embeds democratic values and it is a mechanism which domestic, societal and to a greater degree a home grown factor that influences good governance (Prezworski et al, 2000: Inglehart and Welzel, 2005; Epstein et al, 2006). In addition, economic development created by transnational links, reduces class struggles by fomenting liberal thinking as well as political norms such as human rights, and the rule of law, which normally ensue into a liberal tolerant society.

Conversely, at the sub-national level transnational links become a contact between these countries and the outside world. The good governance influence agenda gives them an enhanced role, as national governments are seen to be less honest and competent. They also, act as political actors because the EU is at times able to use them as an alternative channel of policy influence, thus reducing the level of leverage available to the three countries on resisting EU demands.

In the absence of leverage, transanational links are more effective, because the success of leverage to influence will depend on the degree of those links as they create an intermestic constituency, which connects the domestic with the international. They can be major agents of good governance policy diffusion and international development cooperation; because influences through them can easily be incorporated into the operating procedures of domestic administrations and they become a habit. It is this state-society nexus as we can see Fig.1. below which helps us to account for the variance in EU good governance policy influence among the three countries.

Insert Fig 1 in here.

Leverage will heavily emphasise arrow (1) and to an extent arrows (2) and (3) in the diagram above. Arrow (1) is largely uni-directional running from the EU to the governance institutions of the three countries and the practice is largely compliance (or no compliance).

The difference in the level of good governance policy influence by the EU among the three countries can be understood, however, if we go beyond the focus of arrow (1) analyse the complex web of interactions expressed (and still simplified) by arrows (2) to (9) which heavily represents linkage.

The interaction between aid-recipient country government actor and domestic veto players (the existence of trans-national linkages) to whatever their identity and nature is crucial to understand the complementary nature of the two modes. In addition, EU actors increasingly work directly with civil society and domestic veto players' arrows (7) in those countries surpassing the state authority. In this case linkage and leverage complement each other in transmitting values from the EU and influencing the domestic society in the three countries. In cases of a 
large existence of transnational links in the domestic setting, the influence exerted by leverage will also be increased. Therefore, understanding the state vis-à-vis society provides an inclusive analysis on the role and effectiveness of the $\mathrm{EU}$ in the good governance promotion agenda.

Whilst, the preceding discussion has argued that the effectiveness of good governance policy influence through leverage is dependent on the level of trans-national links, key questions concern the strength of these relationships and whether there are significant differences in policy influence. This variance can be complementarily ascertained by a regression analysis below, which identifies different relevant data and intervening variables. This informs us of where to look for EU-African great lakes states policy failure and success in targeting policy priorities for good governance promotion.

\section{Method and Data}

The regression is pooled time series analysis. The data covers three countries, Uganda, Kenya and Tanzania, for the time period 1975-2009. Though the analysis begins before the good governance policy agenda became a fundamental element of the tie-in, EU implicitly applied minimal good governance demands through human rights conditionalities (Lome IV, Article. 5(2) and the ensuing Uganda guidelines (Note 1).

The dependent variable 'EU multilateral aid' is measured by European Union Development fund (EDF), calculated as a percentage of government expenditure in each of the three countries. The data is obtained from EU-ACP development aid statistics (Note 2). Since, the study investigates EU influence of good governance in the three states; the elements of good governance are derived from the broad good governance concept as stated by the Cotonou Agreement (Article 9.3). Empirically, we can deduce the following independent variables:- Political freedom, Democratization, Economic Liberalism, Human Rights, Rule of law, Low corruption and Low-military expenditure.

The Political freedom variable captures the respect for the law, together with civil and political rights (Karathcky, 1999). This variable is measured by the un-weighted sum of political rights and civil liberties index published by Freedom House (2009). The scale runs from 1-7. 1 represents most democratic and 7 least democratic. In order to facilitate statistical measurement in the regression analysis, I have revised the order of this scale in the opposite direction.

The variable that captures democratization measures the movement towards democracy in each of the three states. In the promotion of democracy as a value, through political and economic influence, the EU does not only observe levels of democracy but rewards movement towards it. This variable is measured by the Polity II Data Set, which is designed to indicate longitudinal indicators of political structures and regime change (Gurr, and Jaggers, 1995) (Note 3).

The broad good governance concept as defined above includes human rights. The EU is committed to the protection and promotion of these rights (Forsythe, 1989, Tomasevski, 1993). However, the EU influence is limited to basic life integrity rights, such as freedom from torture, arbitrary imprisonment and extra-judicial killings; these are principle rights of high legitimacy because of their universality (Boehr, 1994). Based on this definition, this variable is measured by data from two Purdue Political Terror Scales (PTS) in conformity to the literature (Apodocea and Stohl, 1999) (Note 4). The Rule of law reflects the governments' administrative capacity as a means to enforce the law. It is also a means to protect the rights of citizens in their efforts to enforce accountability from the government (Brautigam, 1991). This is measured by a set of data from ICRG called "law and order" (Note 5).

The EU demands low military expenditures on its aid recipients, as a means to free funds and other resources to address poverty issues, especially in the countries analysed. Equally, by conditioning aid on low military expenditures to relatively rich aid recipient states the EU decreases potential military threats as a means to promote international peace (Zanger, 2000; Byrd, 1991). This variable is measured by data from Stockholm International Peace Research Institute (SIPRI) and compared with World Bank data (2008) and data from US Bureau of Arms Control. (2008). Prevention of corruption is an essential element in the EU broad good-governance influence agenda. Defined by ICRG, as a misuse of public power for private benefit, corruption is assumed to be one of the major causes of low government revenue in the three countries (Mugyenzi, 2008). It is measured by data from the International Country Risk Guide. (ICRG) (Note 6).

In order complement its aid resources in aid recipient countries, the EU aims at implementing economic freedom in those countries. This variable is measured with data taken from the Fraser Institute of Economic Freedom (Gwartney and Lawson, 2000). As in most quantitative studies (Nuemeyer, 2003a; Maizels and Nissanke 1984), I do control however, for donor interests and recipient needs. To measure transnational exchanges, I use historical ties between the EU and the individual three countries. Like in other studies (Alesina and Weder, 2000; Gulhati and Narali, 1998), 
historical links influence aid giving and aid is an instrument of international collaboration through trade and expert exchanges. I measure this variable by the number of years the EU has had political and economic relations with each of the three countries from 1975-2009.

To further capture transnational networks in this study, I use the variable Soft Security Policies of Migration (SSPM). As argued by (Olsen, 2000), EU promotion of democracy and economic assistance were probably the most effective civilian means of promoting global stability and enhancing European security. Therefore, the promotion of democracy through economic instruments is a civilian power meant to transfer and promote stability as a preventative soft-security policy. This variable is measured by EU weapons sales to the three countries and taken from US Bureau of Arms Control (1995, 1998, and 2004), the World Bank (2004) and Encyclopaedia Britannica (2001). Additional, variables to capture transnational links included in the model are trade, and Foreign Direct Investment (FDI). I interpret the findings of a number of statistically significant good governance variables to indicate the extent the EU is able to influence these policies in the three countries.

\section{Empirical Estimates}

\subsection{Kenya}

Kenya illustrates many examples of transnational exchanges (linkage) with the EU. Among the three countries it has the largest number of the World's largest industrial corporations on the Fortune 100 list from the EU namely, BP, Total Fina Elf, Volkswagen, Siemens, AXA, Fiat and Peugeot as well as Royal Dutch/Shell until very recently. In addition, EU is Kenya's largest trading partner outside Africa with 35\% exports and 31\% imports, which account for 40-60\% of its Gross Domestic Product (GDP) (Kenya Bureau of Statistics 2006) (Note 7). Equally, historical and social links pre-dominate since the colonial period with an ethnic group of settlers as well as a number of non-governmental organisations from the EU (Nzomo, 1994; Pinckney, 2001). As observed in the model, (Table 1, Column 2), Historical ties together with Trade links variables indicate statistically significant coefficients. Linkage is further buttressed by its positive attraction of EU private financial flows than Uganda and Tanzania (EU Donor Atlas, 2007-2011), this high level of linkage makes Kenya highly vulnerable to EU influence.

Like all aid recipient countries, Kenya, is also vulnerable to EU leverage through its aid. Kenya is classified as medium level, EU aid recipient with per capita aid between US\$ 70-140 (EU Aid Atlas 2006). Such reliance on aid for its development trajectory creates a propitious ground through aid conditionality on which leverage is practised. As a consequence the results in Table 1, Column 2, indicate statistically significant predictors. Good-governance in the form of human rights, democratization, economic freedom and low corruption together with SSPM capture EU good-governance influence through aid. Its ties with the EU through linkage make it a relatively strong case for the practise and efficacy of leverage than either Tanzania or Uganda. In addition, Kenya is highly dependent on external aid, with EU aid accounting for $16 \%$ of government expenditure. Though the efficacy of EU leverage is relatively low than linkage, leverage through aid exerts enormous significance at least up to $10 \%$ as seen in the regression.

Kenya attracted EU and donor attention, when it emerged as a high case of corruption and authoritarianism together with human rights abuses under President Arap Moi in the 1990s (Delegation of the European Commission, 1998:3; Brown, 2004b). These practices led the European Commission to demand for a slimmer government and decided to route most of the aid through NGO's. This was with the aim of strengthening these bodies so that they are more effective political advocates, which would build on stronger transnational links to check on government authority (Goldsmith, 2001; Pinkney, 1999).

Kenya provides a good example on how the EU and other donors tried to use the established linkages (civil society groups) and leverage in the 1990s to induce democratic change. Demands for political liberalism by Western aid donors in the 1990's were more effective in forcing the regime of Arap Moi to allow multi-parties, to establish an impartial elections body, to reinstate a secret ballot, and to relax censorship of the press (Mailafia, 1998; Carothers 1995, Robinson 1995; Cohen, 1995; Brown, 2005). Kenya, however, also illustrates the ineffectiveness of linkage in the absence of leverage. The Regime of Mwai Kibaki, in 2008 was able to manipulate the elections board to rig the elections in its favour so that they could stay in power after mass killings in the country. These actions were possible because there were no credible threats of withdrawing aid by the EU and other Western donors, like in the regime of Arap Moi, if the elections had not been carried out transparently and the outcome respected.

It is the combined international pressure, represented by leverage and transnational linkages, which are responsible for the transmission of ideas and policy. These together with leverage as well as domestic links are responsible for the many statistically significant good governance variables for the case of Kenya than in Uganda and Tanzania as seen in the model. Leverage through political aid conditionality is more effective in achieving the desired policies, even through policy dialogue only when it is complemented by both domestic and transnational linkages. The demands from the domestic groups create a spiral effect from within society resulting into an intermestic 
constituency that can act in consort with both the domestic society and the international community. It becomes very hard for the government to play off these demands' because it is targeted from all corners

\subsubsection{Uganda}

Uganda's strong dependence on the EU for its aid and trade makes it susceptible to leverage mainly through conditionality. Uganda's EU aid share is above $50 \%$, but low per poor person among the population with only US\$ 1-70 (EU Donor Atlas 2006-2011). The EU is its most important trading partner outside Africa with a trade share between 25\%-50\% (EU Aid Donor, 2007; Uganda Bureau of Statistics, 2009). This heavy dependence provides a very high case for leverage. As a consequence, the need to attract development finance and maintain a lucrative market for its agricultural exports is sufficient large to induce far reaching concessions on Uganda. EU leverage through conditionality has to some degree resulted in economic and political liberalism in the country. Leverage, as seen in Fig. 1. Section 2.1.1, has operated at state level without influencing the domestic society, which would have acted in unison with the EU to demand for broad liberal policies on the state.

Despite its historical relationship with the EU, its social-ties through educational links, transnational corporations and non-governmental organizations, there is a low manifestation of these linkages in the country. To some extent, these links are bolstered by EU's provision of technical support in the training of the civil-servants, the civil society, and the political society through decentralized co-operation. Although the country was one of the political liberalism laggards, EU good governance influence on Uganda, was minimal with demands made on the basis of corruption and mismanagement of funds other than the broad good governance policies.

The minimal influence is confirmed by the empirical results (Table1.Column 3), which indicate that only the rule of law is statistically significant among all the good governance variables. This contradicts the theoretical explanations derived from EU policy interests of promoting good governance through aid (EU Council of Ministers 1991). Nonetheless, there are explanations for non-statistically significant variables. These may have been the facade from extreme prolonged emergencies, the history of Uganda's civil wars, the involvement in the African great lakes regional conflicts and the Aglophone-Francphone divide within the EU camp (Kasfir, 1991; Rajoharison, 1999; Youngs, 2007).

These led to sympathetic feelings of humane internationalism that compelled the EU to fund Uganda with minimal demands to implement broad liberal policies. Ineffectiveness of EU policy influence in Uganda is also, partly due to wanting competent good policy agents that are able to coherently bargain with the EU. This is because of Uganda's prolonged emergencies, which led to policy interruptions and the loss of competent policy actors during the wars. Besides, EU funding may have continued because of the impact of post 9/11 as Museveni is deemed to be an ally on the "war on terror" with recent military contributions to the African Union Mission to Somalia.

The qualitatively low levels of linkage mechanisms from the EU, that would lock-in policy implementational structures between governmental actors, individuals and organizations justifies the paucity of liberal policies in the country. Leverage has not been sufficient enough to establish cohesive interest groups that would have defended good governance policies, so that in its absence, there is a political pressure to maintain the policies. EU influence through leverage has been benign in the country because the demands have not set up a system of interest group politics, which would dominate political decision taking. Interest groups even when they exist are disorganized; incoherent and puny as a consequence they cannot maintain many of the resilient policies (Flanary and Watt 1999; 529).

According to Crook (1999), Uganda operated and remained as a one party authoritarian state when President Museveni came to power in 1986. This practice continued until the introduction of multi-party politics in 2006. The transition from one party movement system of government has created a pseudo-illiberal electoral political system intended to play off donors for continued financial support, but not to embed liberal policies. The ruling political elites have stayed in place with the same faces since 1986. The maintenance of the same individuals is to diffusely distribute benefits (spoils of power) in fear of a more concentrated distribution that would lead to political pressure.

Leverage as seen above has limitations; the success of economic liberalism by Museveni government in the period 1995 and 1996 (World Bank, 1993: 137; Delegation of the European Commission, 1996:2; Dijkstra, 2002) was not necessarily a consequence of donor influence and in favour of efficiency, but relational contracts. Though, Museveni argued that it was intended to 'tap the energies of people' and that 'because we believed it best' (Museveni 1998:181), it was illusory as a policy intended for efficiency. It led to economic freedom policies being in a state of creeping normalcy with its benefits not serving the masses. EU good governance influence, here was effective because of relational contracts that had been established as a result of linkages in the interest of apportioning the resources to themselves. Its leverage can be strengthened through links that create strong domestic interest groups or 
policy networks that would build into a broad constituency that is an entanglement of both the domestic and international.

\subsubsection{United Republic of Tanzania}

Tanzania has had strong ties with the EU at state to state level, which has made it a priority EU aid recipient among the three countries. According to EU Donor Atlas (2007) it receives more than 50\% of its ODA from the EU and in $1978 \mathrm{EU}$ aid accounted for $18 \%$ of its development funds. In per capita terms, in 2003-2004, it received US\$ 25 million compared to Uganda US\$ 17 and Kenya US\$ 15 (EU Aid Atlas, 2006-2007) making it the largest recipient of EU aid in the Region. Lending further credence, to EU influence is that it manifests a positive attraction of EU private flows between US\$0-500 million than Uganda and Kenya (EU Donor Atlas, 2007). The influence by EU transnational linkages represented by commercial enterprises like Shell until very recently, B.P. Lonrho enterprises, Vodafone and a number of mining companies, than those from the US, Japan or China cannot easily be discounted (Mutambalya, 1999).

Its economic dependence on exports of mineral and agricultural nature have made the EU its biggest trading partner outside Africa, absorbing 38\% of its exports and supplying 21\% of its imports (Ministry of Finance, Tanzania Bureau of Statistics, 2007). Such dependence, aimed at maintaining EU aid and markets makes it highly vulnerable to EU leverage and linkage mechanisms. Hence the presence of a number of statistically significant regressions in the model, the most statistically significant coefficient is between EDF and Economic Freedom. This indicates that Tanzania has followed EU demands to economically liberalise so as to be integrated in the global economy (Pallotti, 2008; Holland, 2002).

Furthermore, EU good governance influence was mainly focussed on economic freedom with the belief that the gains from economic freedom would spill over to political liberalism transforming the society. The spill-over effects of economic liberalism are seen to be more effective because they create a strong civil society and domestic linkages. In the absence of leverage and direct links, these linkages are able to continue exerting the pressure exacting good governance policies from the grass roots. Economic liberalism, creates groups that cannot easily be bought off by the ruling elites because they posses financial backing and connections to thwart the ruling party pressure. That is why when multi-party politics started in 1995; it was mainly a combination of local traders and other business people who formed the main opposition party, the National Convention for Reconstruction and Reform (NCCR).

As observed in (Table 1, Column 1) other significant variables include Political Freedom, Democratization, Low Corruption and Foreign Direct Investment at 10\% confidence. The EU through leverage has been able to influence Tanzania, though minimally, with good governance policies. Leverage adds on linkage mechanisms which are hinged on domestic factors. These factors are responsible for the extent and number of significant good governance variables. As argued by Jardine (2008-09), domestic factors play a considerable role in democracy promotion in any society. Additionally, economic freedom was possible through aid conditionality because it was buttressed by the existing commercial linkages from the EU that had transmitted liberal ideas and values, which were in companion with EU demands. The more significant number of variables in the model may be due to the well established linkages from the EU ranging from non-governmental organizations to commercial enterprises in the country.

In the case of political liberalism, internal peace allowed stability with a propensity to embrace the unknown, without fear of war or lack of basic commodities as they had been in much worse conditions economically. It is this internal milieu that facilitated the spread of liberal ideas. The country was a socialist command economy and with the fall of the Berlin Wall and the collapse of communism in Russia and socialism in China, there was need to change in favour of the triumphant liberal capitalist policies. Tanzania had experienced economic problems because of its economic and social policy (Hyden, 1999). As a consequence there was domestic pressure on the state to embrace a new system with the aim of becoming economically stable and providing its population with the basic necessities. As argued by Bates (2006) internal peace and presence of political order help to maintain skilled manpower from one regime to another. This has been instrumental in efficiently embedding liberal policies in Tanzania, because they were able to embrace a new political and economic system easily. The weakness of good governance policies in the country is because the EU and other Western donors have mainly relied on leverage to influence these policies without domestic linkages (Diamond, 1995; Burnell, 2010).

EU use of leverage through aid conditionality indicates the inadequacies of external pressure in enabling good governance and helps to explain the current minimal influences and strengths of good governance in the country, as well as broad policy divergence explanations. There are no strong indigenous groups in the country that can be sources of good governance policies, they are still dependent on EU financial influence, support and advice (Duhu, 2005; Pinkney, 2001), hence the apparent weaknesses. As argued above, Leverage alone is less effective in Tanzania, because of low levels of linkage exerted by transnational networks that are linked to the EU. EU influence through 
leverage would be enhanced, if it is complemented by demands for implementation with similar policies within the domestic society.

\section{Policy Implications and Conclusion}

The EU like all other multilateral aid donor bodies has come under intense scrutiny for use of leverage through conditionality to influence third countries with good governance policies. The criticism has centred on the aid moral hazard and the ineffectiveness of aid conditionality by donors to achieve desired objectives in third states (Mwenda, 1999; Kappur and Webb, 2000; Goldstein, 2001; Riddell, 2007; Moyo, 2009). Although most assert that aid has not achieved its intended objectives, EU aid conditionality since 1975 within the Lome-Cotonou framework has had a distinctive influence in the three countries.

The statistical results suggest that leverage through aid conditionality has an effect on good governance policies in the three countries. Nonetheless, Leverage through aid conditionality is not so effective in achieving EU desired policies in the three countries because it operates at European Union to state level. The findings further indicate that countries with well established linkage mechanisms from the EU like Kenya and Tanzania manifest more statistically significant good governance variables. Leverage is more effective in influencing polices when complemented by linkage mechanisms and a strong domestic civil society. This is because linkage creates cohesiveness in society, so that society is able to favour the implementation of policies that broadly benefit it.

In addition, the findings indicate that domestic factors are important in explaining good governance policy influence among the three countries. An inclusive use of both transnational linkages and leverage better indicates the extent the EU is able to influence good governance polices. The study has indicated that Leverage plays a significant role in policy influence, but its efficacy is dependent on the level of transnational links, which complement its pressure. Consequently, EU use of leverage to influence third countries is benignly effective when it is applied on its own, even to a highly aid dependent country, like Uganda. Leverage directed towards the state will have an effect, which will not percolate into society; its effects are not reflected in the needs of the domestic constituents.

Furthermore, the findings of this analysis suggest several possible policy approaches on how the EU can influence good governance policies in the three countries. First, EU could direct a larger portion of its aid resources in the unitary improvement of good governance policies. EU use of economic policies to influence political and economic stability in the three countries should be directed broadly at all actors. Funding should not only be directed towards the support of NGOs as the practice has been (Youngs, 2001) but, to all social development that enhances micro-level ownership of policies. Second, aid could also, be directed at participatory decision-making organizations like trade unions and church based organizations to ensure their participation in policy. Third, aid in form of subsidies could be offered to EU companies that are willing to establish, industries in third countries. This is in a view that these companies would transfer EU values of economic freedom to the personnel they employ who could easily diffuse this knowledge into the domestic society.

In view of strong good governance policy influence, the EU through decentralized co-operation, should by-pass state authority and devote greater efforts to strengthen the domestic civil society. This should go beyond to political society groups like political parties, local-government and parliaments, which would entrench good governance policies within society. With the longest aid model in history to these countries, the EU could direct a large portion of its aid in support of projects locally initiated by the people not government ministries of finance. This would expand the domestic constituency that identifies itself with EU values and at the same time may be enabled not to be easily bought off by the government. This will in turn assist EU leverage to become more effective in achieving its demands. Lastly, this study like other studies (Koeberle, 2003; OED, 2004; Morrissey and Nelson, 2004) has indirectly shown that EU use of economic instruments is effective, when it used as an instrument of leverage in policy influence. However, policy implications must be phrased, very tentatively pending additional research.

\section{References}

Alesina, A., \& Weder, B. (2000). Do corrupt Governments receive Less Foreign Aid? Mimeo, Cambridge, MA and Basel Harvard University Press.

Apodocea, C., \& Stohl, M. (1991). United States Human Rights Policy and Foreign Assistance", International Studies Quarterly. 43:185-98. http://dx.doi.org/10.1111/0020-8833.00116

Asante, S. (1996). The European Union-Africa (ACP) Lome, Convention, Africa Insight, vol. 26 (4).

Bates, R. (2006). Institutions and Development. Journal of African Economics. Vol. 15, Supplement 1. http://dx.doi.org/10.1093/jae/ejk005

Bauer, P.T. (1984). Reality and Rhetoric: Studies in the Economics of Development. Cambridge : Harvard 
University Press.

Brautigham, D. (1991). Governance The World Bank Policy and Review Dept. Working Paper series No. 815.

Brown, S. (2004b). Theorising Kenyas's Protracted Transition to Democracy. Journal of Contemporary African Studies. Vol.22No.3:325-42.

Brown, S. (2005). Foreign Aid and Democracy Promotion: Lessons from Africa. The European Journal of Development Research. Vol. 17. No.2. June: 179-198. http://dx.doi.org/10.1080/09578810500130799

Burnell, P., \& Schlumberg, O. (2010). Promoting democracy-promoting Autocracy? International Politics and National Political Regimes. Contemporary Politics, 16 (1):1-15. http://dx.doi.org/10.1080/13569771003593805

Byard, P. (1991). Foreign Policy and Overseas aid in Anuradha, B. and Burnell, P.(eds) Britain Overseas Aid Since 1979: Between Idealism and Self-interest, pp.49-73. Manchester: Manchester University Press.

Carothers, T. (1997). Democracy Assistance, the Question of Strategy. Democratization, Vol. 4, No. 3, pp. 109-132. http://dx.doi.org/10.1080/13510349708403527

Cohen, J.M. (1995). Ethnicity, Foreign Aid and Economic Growth in Sub-Saharan Africa: The Case of Kenya. Harvard Institute of International Development, Development Paper No. 520, Cambridge, Mass. Harvard Institute for International Development. PMid:5710584

Courier. (1982). The Pissani Memorandum. Number 76, Brussels European Commission, Nov.-Dec. pp.10-28.

Delegation of the European Commission (1998) Co-Operation between the EU and Republic of Kenya: Annual Report, Brussels, European Commission. PMid:5675398

Dijkstra, A.G. (2002).The Effectiveness of Policy Conditionality: Eight Country Experiences Development and Change, 33:307-34. http://dx.doi.org/10.1111/1467-7660.00256

Duhu, J. (2005). Strengthening Civil Societyin the South: Challenges and Constraints-a Case Study of Tanzania. The International Journal of Not-for-Profit Law. Vol. 8(1).

EEC-EAC. (1969). Agreement Establishing an Association Between the European Economic Community and the United Republic of Tanzania, the Republic of Uganda and the Republic of Kenya and Annexed Documents. Brussels. EEC. 1969. (Second Arusha Convention).

Encyclopedia Britannica. (2010). Britannica Book of the Year, Chicago: Encyclopedia Britannica.

Epstein, D.L. Bates, R. Goldstone, J. Kristensen, I., \& O’Halloran, S. (2006). “Democratic Transitions” American Journal of Political Science, (50)30:551-69. http://dx.doi.org/10.1111/j.1540-5907.2006.00201.x

EU Donor Atlas (2006-2011). Mapping Development Assistance available at www: http/l e.c europa.eu/europeaid/how/ensure-aid.../eu-donor-atlas.en.htm, Source OECD DAC International Development Statistics (IDS). (29/12/2011).

European Union Council of Ministers (1991). Resolution of the Council and the Member States meeting in the Council of Rights, Democracy and Development.

European Union Foreign Affairs Review, vol. 6(3)

Flanary, R., \& Watt, D. (1999). The State of Corruption: A Case study of Uganda. Third World Quarterly, 20(3): 515-36. http://dx.doi.org/10.1080/01436599913668

Goldsmith, A. (2001). Foreign Aid and Statehood in Africa. International Organization, Winter, Vol.55, No.1.

Gulharti, R. \& Nallari, G. (1988). Reform of Aid Policies: The Issue of Inter-country Allocation to Africa. World Development, 16:1167-84. http://dx.doi.org/10.1016/0305-750X(88)90084-8

Gwartney, J. \& Lawson, R. (2000). Economic Freedom of the World: 2000-2006, Annual Reports, Vancouver, B.C. Fraser Institute.

Hass, E.B. (1990). When Knowedge is Power. Berkley: University of Carlifornia Press.

Hyden, G. (1999). Top Down Democratization in Tanzania. Journal of Democracy. Vol. 10(4) 142-155. http://dx.doi.org/10.1353/jod.1999.0066

ICRG, (2002). The Rating System, http:icrgonline.com.

Inglehart, R., \& Welzel, C. (2005). Modernization, Cultural Change and Democracy: The Human Development Sequence. Cambridge, Cambridge University Press.

Jaggers, K., \& Ted, R. G. (1995). Tracking Democracy's Third Wave with the Polity III Data. Journal of Peace 
Research 32(4): 469-82. http://dx.doi.org/10.1177/0022343395032004007

Jardine, E. (2008-09). Domestic Experience and its Effects on Democracy Promotion Innovations. A Journal of Politics. 8:86-98.

Kalu, A.K. (2004). Agenda Setting and Public Policy in Africa. Aldershot, Ashgate Publishing.

Kapur, D., \& Webb, R. (2000). Governance-Related Conditionalities of the IFIs. Revision of paper prepared for the XII Technical Group Meeting of the Intergovernmental Group of 24 for International Monetary Affairs, 1-3 March, Lima, Peru.

Karathyky, A. (1999). Freedom in the World. Annual Survey of Political Rights and Civil liberties (1998-1999). New York, Freedom House.

Kasfir, N. (1999). "No-Party Democracy in Uganda in Diamond and Platner (eds)", Democratization in Africa. Baltimore, Hopkins University Press.

Koeberle, S. (2003). Should Policy-based Lending Still Involve Conditionality? The World Bank Research Observer. 18(2): 249-273. http://dx.doi.org/10.1093/wbro/lkg009

Levitsky, S., \& Lucan W. (2006). Linkage Versus Leverage: Rethinking the International Dimensions of Regime Change.Comparative Politics. Vol. 38(4) 379-400. http://dx.doi.org/10.2307/20434008

Mailafia, O. (1998). Europe and Economic Reform in Africa: Structural Adjustment and Economic Diplomacy in Africa. London, Routledge.

Maizels, A., \& Nissanke, M.K. (1984) Motivations for Aid to Developing Countries. World Development. 12:879-900. http://dx.doi.org/10.1016/0305-750X(84)90046-9

McCormick, J. (2005). Understanding the European Union: A Concise Introduction. London. Palgrave.

Moor, M. (1998). "Death without Taxes: Democracy, State Capacity, and Aid Dependence in the Fourth World" in G. White and M. Robinson (eds), Towards a Democratic Developmental State. Oxford: Oxford University Press.

Morrissey, O., \& Nelson, D. (2004) "The Role of the World Bank in Transfer of policy knowledge on trade liberalization in D. Nelson(ed)". The Political Economy of Policy Reform. Elsevier.

Moyo, D. (2009). Dead Aid: Why Aid id Nit Working and How There is a Better Way for Africa. Macmillan.

Mugyenzi, T. J. (2008). Promoting Good-Governance in the African Great Lakes Region. Unpublished PhD. Thesis. University Kent.

Museveni, Y. (1998). Sowing the Mustard Seed. Basingstoke, Macmillan.

Mutambalya, F. (1999). Economic Partnership Agreements and Regional Integration among ACP States. Dar-es-Salam, Friedrich Ebert Stiftung.

Mwenda, A. (1999). Domestic Debt Record Shillings 100 billion, IMF Suspends Aid to Uganda. The Monitor, Kampala, $13^{\text {th }}$ March.

Nuwamayer, E. (2003a). Determinants of Aid Allocation by Regional Development Banks and United nations Agencies International Studies Quarterly, 47.

Nuwamayer, E. (2003b). The Pattern of Aid Giving: The Impact of Good Governance on Development Assistance, London, Routeledge.

Nzomo, M. (1994). "External Influences on Foreign policy of Kenya" in Walter Oyugi (ed) Politics and Administration in East Africa, Nairobi, East African Educational Publishers pp. 429-67.

OECD (2004). Annual Review of Development effectiveness: the Effectiveness of Bank support for Policy reform, Washington DC: World Bank Operations Evaluations Dept.

OECD. (Various Years) Development Cooperation Paris OECD

Olsen, G. (2000). Promotion of Democracy as a Foreign Policy Instrument: The Limits of Idealism. Democratization. Vol. 7(2):142-167. http://dx.doi.org/10.1080/13510340008403663

Pallotti, A. (2008). Tanzania: Decentralising Power or Spreading Poverty? Review of African Political Economy. 116: 221-235. http://dx.doi.org/10.1080/03056240802194067

Partnership Agreement. (2000). ACP-EU Partnership Agreement Signed in Cotonou on 23 June. Supplement to The Courier. Brussels. European Commission.

Pinckny, R. (2001). International Politics of East Africa. Manchester and New York, Manchester University Press. 
Pissani, E. (1981) Speech to ACP-EEC Consultative Assembly. Strasbourg. $24^{\text {th }}$ September.

Pourgerami, A. (1999). The Political Economy of Development: An Empirical Examination of the Wealth Theory of Democracy. Journal of Theoretical Politics, April (3): 189-211.

Przeworski, A. Michael, E. Alvarez, J. Cheibub, \& Limongi, F. (2000). Democracy and Development: Political Institutions and Well-being in the World, 1950-1990, Cambridge, Cambridge University Press.

Rajorharison, J. (1999). "The Role of France in the Lome IV Convention”, in Cosgrove-Sacks (ed). The European Union and the Developing Countries: The Challenges of Globalization, Basingstoke, Macmillan.

Riddell, R. (2007). Does Foreign Aid Really Work? New York, Oxford University Press.

Robinson, M. (1995). "Implications of Political Conditionality" In Political Conditionality, Olav Stokke(ed), London, Frank Cass.

Schimmelfennig, F., \& Sedelmeir, U. (2004). Governance by Conditionality: EU Rule Transfer to the Candidate Countries of Central and Eastern Europe. Journal of European Public Policy 11(4): 669-687. http://dx.doi.org/10.1080/1350176042000248089

Schimmelfenning, F., \& Scholz, H. (2008). EU Democracy Promotion in the European Neighbourhood, Political Conditionality, Economic Development and Transnational Exchange. European Union Politics. Vol. 9(2): 187-215. http://dx.doi.org/10.1177/1465116508089085

Smith, K. (2001)."Western Actors and the Promotion of Democracy" in J. Ziolonka and A. Pravda(eds) Democratic Consolidation in Eastern Europe, Vol 2. International and Transnational Factors, Oxford: University Press. pp. 31-57.

Stallings, B. (ed) (1995). Global Change and Regional Response, the New International Context of Development. Cambridge University Press. Cambridge.

Stockholm International Peace Research Institute (SIPRI) (2011). Armaments, Disarmament and International Security. Oxford. Oxford University Press.

Stoker, G. (2006). Why Politics Matters: Making Democracy Work. Palgrave. Macmillan. London. Transparency International (Several years) Available at http://www.transparency.org/policyresearch/surveysindeces/cpi $(29 / 12 / 2011)$

Tomaseveski, K. (1993). Development Aid and Human Rights Revisited, London, Palgrave.

Uganda Bureau of statistics (2001-2008) available at http://www.ubos.org/abstractpdf/foward.pdf (29/12/20011)

United States Bureau of Arms Control (1995-2008). World Military Expenditures and Arms Transfers. Washington, DC. US Arms Control Disamament Agency.

World Bank (2004). Country Fixed Factors Database, Washington, DC: World Bank.

Youngs, R. (2001). European Union Democracy Promotional Policies: Ten Years On, European Foreign Affairs Review, Vol.6 (3).

Youngs, R. (2008). “What Has Europe Been Doing?” Journal of Democracy Vol. 19(2) April.

\section{Notes}

Note 1. The "Uganda Guidelines" is a term which is used to refer to the Council Declaration on the situation of human rights in Uganda under Idi Amin, in which consistent denial of basic human rights to the people of Uganda was deplored. Under the suspension most of the aid from even European bilateral donors reduced, but Stabex transfers from the community continued to be disbursed, this was because the Uganda Guidelines did not entail a formal denunciation of the Lome IV Agreement.

Note 2. Aid here as defined by Development Assistance Committee (DAC) are all those flows to developing countries and multilateral institutions provided by official agencies, including states and local governments, or by executive agencies: They must be administered to promote the welfare and economic development of developing countries and concessional in character with a grant element of at least 25 percent (Geographic Distribution of Financial Flows to Aid Recipients, DAC, 1997:249).

In calculating the value of the dependent variable, I have departed from the previous studies, (Nuewamayer, 2003; Zanger, 2000), who use per capita ODA. Instead, I have used EDF as a percentage of government expenditure. This has been done to take into account that the three countries are;- i) heavily dependent on aid to carry out their functions. ii) The percentage of EU aid as government expenditure best approximates the needs of governments and 
the way the donor undertakes aid allocations, unlike per capita aid allocations which take into consideration the whole population. iii) Bauer(1984) asserts that aid as a percentage of government expenditure is more appropriate because aid goes to governments, not people and Moore(1998) defines aid dependence as a characteristic not of economies but governments. I agree with both. Data for this variable is can be retrieved at http://europa.eu.int/comm/development (19/8/2011)

Note 3. Data is found at http://www.colorado.edu/iBS/GAD/spacetime/data/polity.html. (7/8/2009)

Note 4. Data is available at http://www.ippu.purdue.edu/info.gsp/govern.html.(27/12/2011)

Note 5. Data is available at the ICRG website. http;//www.icrgonline.com. (18/10/2011)

Note 6. Data is available at http://www.icrgonline.com (18/10/2011)

Note 7. Data is also, available at http://knbs.or.ke (27/12/2011)

Table 1. Results of pooled time-series regression for EDF and independent variables (1975-2009). The Dependent Variable is EDF as a percentage of government expenditure.

\begin{tabular}{|c|c|c|c|c|c|c|}
\hline \multirow[t]{2}{*}{ Variables } & \multicolumn{2}{|c|}{ Tanzania } & \multicolumn{2}{|l|}{ Kenya } & \multicolumn{2}{|l|}{ Uganda } \\
\hline & Beta & $\mathrm{t}$ & Beta & $\mathrm{t}$ & Beta & $\mathrm{t}$ \\
\hline Political Freedom. & -.788 & $-1.910^{*}$ & & & -1.175 & -1.066 \\
\hline Democratisation & .515 & $1.292^{*}$ & -.279 & $-1.804 *$ & -.169 & -.228 \\
\hline Human Rights & -.119 & -.711 & -.327 & $-3.050 * * *$ & .329 & .729 \\
\hline Rule of Law & .300 & .938 & -.087 & -.802 & 1.018 & $1.385^{*}$ \\
\hline Low Military Expend. & -.225 & -.487 & -.089 & -.508 & .006 & .015 \\
\hline Low Corruption & 1.308 & $1.853^{*}$ & .396 & $1.614^{*}$ & .131 & .292 \\
\hline Economic Freedom & .990 & $2.105^{* *}$ & .181 & .533 & -1.055 & -.642 \\
\hline Historical ties & -1.331 & -.308 & -1.568 & $-1.591^{*}$ & .7 .734 & .988 \\
\hline SSPM & .212 & 1.225 & .585 & $2.197 * *$ & .346 & .515 \\
\hline Trade & -.329 & -.695 & .337 & $1.855^{*}$ & .159 & .200 \\
\hline FDI & -3.348 & $-1.405^{*}$ & -.121 & -.817 & .339 & .494 \\
\hline GDP per capita & -1.448 & $-2.089^{* *}$ & .212 & .209 & -5.365 & -1.254 \\
\hline PQLI & .272 & .566 & .153 & $1.417^{*}$ & -.314 .494 & -.475 \\
\hline Population Size & 4.141 & $1.542^{*}$ & 1.028 & .775 & -1.279 & -.445 \\
\hline r2 & & .992 & & .932 & & .884 \\
\hline Adjusted r2 & & .933 & & .883 & & .479 \\
\hline$F$ & & 16.958 & & 18.929 & & 2.184 \\
\hline F Significance & & .057 & & .000 & & .235 \\
\hline
\end{tabular}

Coefficients of Constants not reported.

*Significant at $10 \%$

** Significant at $5 \%$

*** Significant at $1 \%$ 


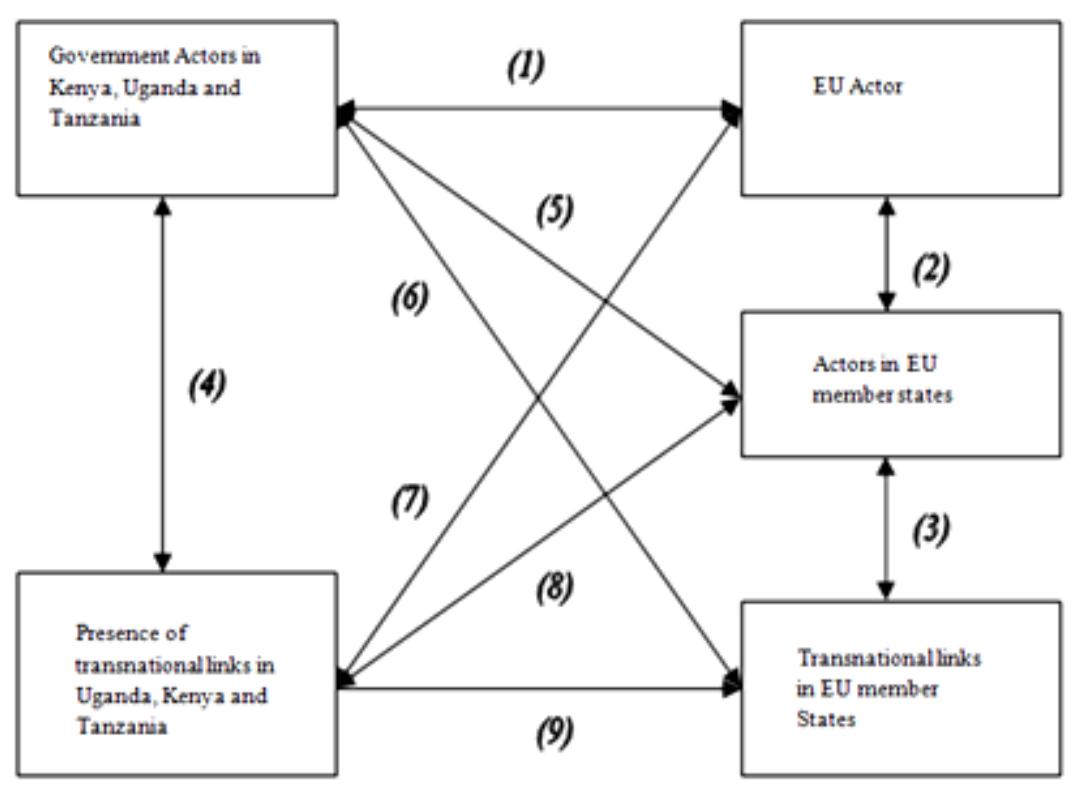

Figure 1. Complementary Role of the Modes 